This item was submitted to Loughborough's Research Repository by the author.

Items in Figshare are protected by copyright, with all rights reserved, unless otherwise indicated.

\title{
Factors influencing time allocation of sport event volunteers
}

\section{PLEASE CITE THE PUBLISHED VERSION}

https://doi.org/10.1108/IJEFM-01-2018-0004

\section{PUBLISHER}

(C) Emerald

\section{VERSION}

AM (Accepted Manuscript)

\section{PUBLISHER STATEMENT}

This work is made available according to the conditions of the Creative Commons Attribution-NonCommercialNoDerivatives 4.0 International (CC BY-NC-ND 4.0) licence. Full details of this licence are available at: https://creativecommons.org/licenses/by-nc-nd/4.0/

\section{LICENCE}

CC BY-NC-ND 4.0

\section{REPOSITORY RECORD}

Hallmann, Kirstin, Paul Downward, and G. Dickson. 2019. "Factors Influencing Time Allocation of Sport Event Volunteers”. figshare. https://hdl.handle.net/2134/33362. 


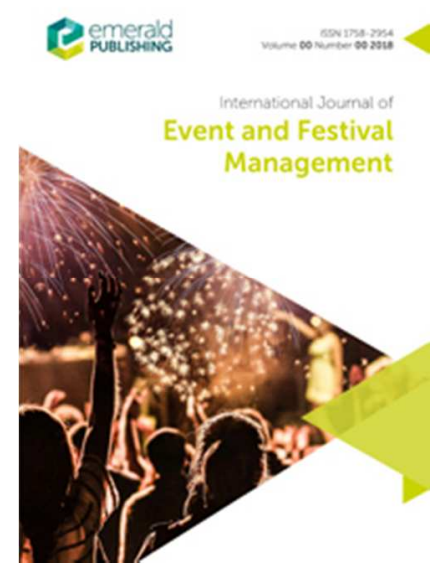

\section{Factors Influencing Time Allocation of Sport Event Volunteers}

\begin{tabular}{|r|l|}
\hline Journal: & International Journal of Event and Festival Management \\
\hline Manuscript ID & IJEFM-01-2018-0004.R2 \\
\hline Manuscript Type: & Research Paper \\
\hline Keywords: & volunteering, multi-level analysis, decision-making \\
\hline $\begin{array}{l}\text { Note: The following files were submitted by the author for peer review, but cannot be converted to } \\
\text { PDF. You must view these files (e.g. movies) online. }\end{array}$ \\
\hline RtC2_IJEFM_EventVolunteers_MultiLevel_180522.docx \\
\hline
\end{tabular}

\section{SCHOLARONE}




\section{Factors Influencing Time Allocation of Sport Event Volunteers}

2

\section{Abstract}

4 Purpose: Given the increasing demands placed on a sport event workforce in servicing the needs of

5 spectators, to attract and recruit volunteers to the industry, it is important for sport event managers to

6 know what is driving how much time volunteers allocate to an event. We investigate the individual

7 and macro level factors influencing the allocation of time to volunteer at sport events.

8 Design/Methodology/Approach: Survey data were collected from volunteers at 25 sport events

$9 \quad(n=2,303)$. Multi-level modelling was used to identify common effects controlling for event

10 differences.

11 Findings: Male gender significantly influences time allocated to an event at the individual level. At

12 the macro level, the number of local inhabitants has a significant negative effect whereas the status of

13 an international event and duration contribute positively to time allocation.

14 Practical implications: The results provide clear evidence that macro level variables can stimulate

15 interest in event volunteering opportunities.

16 Originality/Value: This paper uses a multi-level approach to assess the influence of micro and macro

17 level variables on time allocation by sport event volunteers. Using this approach, event heterogeneity

18 can be controlled.

Key words: volunteering; multi-level analysis; decision-making

21

22 Article classification: Research paper

Word count: 7,971 


\section{Introduction}

2 The global sports event industry was worth $\$ 80$ billion of a total sports market value of $\$ 700$

3 billion in 2014. Since 2007 the sports event industry has continually grown faster than

4 international GDP (Collignon and Nicolas, 2014). The industry is unusual in that it relies

5 heavily on a volunteer labour force, particularly outside of the major professional leagues

6 (Kim and Cuskelly, 2017). Volunteers consequently offer their services to sports event

7 organisers by allocating their discretionary time (Holbrook and Lehmann, 1981). From an

8 organisational perspective, therefore, the amount of time a volunteer allocates is of utmost

9 importance for volunteer managers (Cuskelly et al., 2006) as the consumers (spectators and

10 participants) look for a high-quality service experience. It is the volunteer manager's job to

11 effectively recruit volunteers and to allocate roles and workloads dependent upon the time

12 available and skills of the volunteer to ensure good service delivery. The volunteer manager

13 needs to acknowledge that volunteers are servicing the event but also need to be service

14 managed (Mulder et al., 2015). This paper focusses upon the first of these issues, which is to

15 examine the factors that contribute to the decision of volunteers to allocate time to

16 volunteering at events. These factors are neglected in sport-event volunteering research as

17 will be outlined.

18 A volunteer's individual motivation is an important determinant of both the decision

19 to volunteer and the amount of time allocated in non-profit sport clubs (Hallmann, 2015,

20 Flatau et al., 2012). However, there is a dearth of research regarding the relationships

21 between motivations and the amount of time allocated by sport event volunteers. Attempts to

22 recruit and retain volunteers will lead to better service delivery if the volunteer opportunity

23 meets the underlying motivations to volunteer. From a human resources perspectives, sport

24 events must recruit and retain talent to ensure marketplace competitiveness (Hiltrop, 1999).

25 Moreover, Roza et al. (2017) and Wicker (2017, in press) argue that more research is needed 
1 that investigates how higher level organisational and environmental features of the

2 volunteering opportunity influence volunteer decisions. This paper addresses these gaps in

3 research by integrating individual level variables such as socio-demographics and motivation,

4 with macro level variables addressing the event status, size of local population etc. on the

5 allocation of time by sport event volunteers. This is made possible because whilst previous

6 event-volunteering research tends to focus on single events (e.g., Wollebæk et al., 2014,

7 Alexander et al., 2015), this research draws on data across a number of events and

8 international contexts. The latter is also important because it adds to the generalisability of

9 the research. In the current literature, when two or more events are researched, they are

10 usually from the same country (e.g., Hallmann and Harms, 2012, Bang and Chelladurai,

11 2009), In this study data from multiple events in three countries - Germany, Italy and New

12 Zealand are analysed to address the following research question: What individual and macro

13 level factors influence the time allocated to volunteering at sport events? The purpose of our

14 research is to investigate the general and common effects of socio-economic (i.e. individual

15 level) and event (i.e. macro level) characteristics on the allocation of time to volunteering,

16 thus controlling for potential event differences.

\section{Theoretical Framework}

18 This paper builds on the premise that volunteering can be explained with decision-making

19 theory (Bauer et al., 2013, Brown and Lankford, 1992). Each individual makes a decision

20 whether or not to allocate their time as a volunteer. Neo-classical economics emphasizes

21 decision-making under the constraints of time and income (Frey, 2000). The individual is

22 assumed to act rationally, with perfect foresight and preferences, and tastes are considered

23 invariant when making a choice (Altman, 2006). According to this perspective, the act of

24 giving (i.e., contributing time through volunteering) generates utility for the individual,

25 suggesting that self-interest need not imply selfishness (Apinunmahakul et al., 2009). Yet, the 
1 underlying assumptions of rationality do not hold true for every decision. For example,

2 emotions influence decisions, a feature which emphasizes that preferences are not invariant

3 (Kahneman et al., 1997). Individuals also use heuristics (Tversky and Kahneman, 1971) and

4 intuition (Klein et al., 1986) when making decisions. Nonetheless, the premise that decisions

5 to allocate time to volunteering are made under conditions of scarcity remain shared by both

6 neo-classical and behavioural economists (Angner, 2012). Therefore, determinants such as

7 time, income and education are pivotal for understanding any form of decision-making

8 (Becker, 1965). Time allocated to leisure (e.g., volunteering) is time that cannot be allocated

9 to work and income generation (Burgham and Downward, 2005, Apinunmahakul et al.,

10 2009).

11 Demographic indicators, such as age and gender are also related to the availability of

12 time and income. Schlesinger and Nagel (2013) discuss how career opportunities (i.e.,

13 retirement or raising children) impact the decision to allocate time to volunteering. Finally,

14 psychological indicators like preferences and attitudes (i.e. motives) also determine

15 volunteering either by implicitly regarded as fixed in the utility function (Cappellari et al.,

16 2011), or characterised by “...malleability and context-dependence ...” (Fudenberg, 2006) in

17 behavioural economics research. Behavioural economics research makes clear that the

18 environment/context (i.e., the available set of alternatives and how these are presented)

19 influences decisions (Simonson and Tversky, 1992). It follows that macro level

20 characteristics such as organisational or socio-cultural factors can also influence individual

21 behaviour (Dixon and Bruening, 2007). Put differently, macro level characteristics can

22 constrain the amount of time allocated to volunteering (Wicker and Hallmann, 2013,

23 Schlesinger and Nagel, 2013, Schlesinger and Nagel, 2016, Studer and von Schnurbein,

24 2013). This theoretical underpinning features in sport volunteering studies, though most 
1 studies do not consider all of these potential constraints (e.g., Emrich et al., 2012, Schlesinger

2 and Nagel, 2013, Schlesinger and Nagel, 2016).

\section{Empirical Review}

4 The economic, demographic, psychological, and macro level constraints discussed above

5 have been explored empirically. However, the research focusing on time allocation by sports

6 volunteers has only been studied within the context of organised, non-profit sport clubs

7 (Taylor et al., 2012, Flatau et al., 2012, Dawson and Downward, 2013, Hallmann, 2015).

8 Factors affecting the decision how much time to allocate by event volunteers remain un-

9 investigated. Due to the frequency of occurrence and time-compressed nature of events,

10 volunteers invest their time differently from club volunteers. Event volunteers are likely to

11 commit many hours during a relatively short time frame as they are responsible for the actual

12 operative activities (Ingerson, 2001). It is this feature that makes a study about volunteers and

13 time allocation so valuable.

14 There are mixed findings for the influence of income, time and education on the time

15 allocation of sports-club volunteers. Burgham and Downward (2005) report a positive effect

16 for income and a negative effect for working hours. Dawson and Downward (2013) refer to

17 an individual's income and substitution effects in complex time allocation tasks to explain

18 this finding. Demanding work and/or family commitments can make episodic (i.e. event)

19 volunteering more attractive than continuous volunteering, for example, in clubs (Holmes,

20 2014). Ziemek (2006) emphasizes that educated individuals derive more utility from

21 volunteering. However, Taylor et al. (2012) find no significant relationship for education on

22 time allocation.

23 The evidence regarding the influence of demographic factors on time allocation is also

24 mixed. Factors related to age (e.g., retirement) or gender (e.g., raising children) are important

25 as both may restrict time and income (Schlesinger and Nagel, 2013). Some scholars report 
1 that females allocate more time than males in the context of their children's swimming

2 lessons (Burgham and Downward, 2005), whereas most research finds that males allocate

3 more time to sport volunteering (Taylor et al., 2012, Dawson and Downward, 2013, Skirstad

4 and Hanstad, 2013) or do not find any significant effect of gender on hours volunteered.

5 Becker's (1991) intra-family resource allocation model suggests that those with the lowest

6 opportunity costs are likely to allocate more hours to volunteering. In support of this model,

7 there is evidence that adults whose children play sport are more likely to allocate time to their

8 club (Burgham and Downward, 2005). Similarly, divergent results exist for the influence of

9 age on time allocation. Age is positively associated with the time allocated to volunteering

10 (Taylor et al., 2012), or negatively (Dawson and Downward, 2013), whilst others report no

11 significant effect (Burgham and Downward, 2005). Competence building has been also

12 identified as pivotal motive to volunteer (Skille and Hanstad, 2013). Competencies can be

13 only built through performing a certain task over a certain time period and might therefore

14 also be related to time allocation to volunteering.

15 Psychological factors have also been investigated as motives influencing volunteer

16 time allocation (Flatau et al., 2012, Hallmann, 2015). This is not surprising because people

17 direct their behaviour to fulfil needs (Iso-Ahola, 1989, Shank, 2009) and time-allocation

18 decisions are related to those needs. Intrinsic-egoistic and altruistic motives have been shown

19 to foster time allocation to voluntary activity whereas extrinsic-egoistic motives have no

20 influence (Flatau et al., 2012). In addition, the motives such as 'meeting people' and 'shaping

21 society' (also understood as contributing to society) are positively associated with time being

22 allocated to longer term sport volunteering (Hallmann, 2015). It is clear that such motives are

23 not specifically sport-related and can be fulfilled in other contexts. Consequentially, research

24 suggests that social interaction is essential for volunteers and that a sense of community

25 follows from a feeling of belonging to a group (Kodama et al., 2013). Volunteering more 
1 hours can foster the 'group feeling', because it enables people to interact with each other

2 more. Fulfilling the motive of social interaction can lead to social integration and a strong

3 sense of community. High levels of social integration and a strong sense of community foster

4 volunteer retention (Kristiansen et al., 2015). It follows that a certain time allocated to

5 volunteering is needed so that that sense of community can be created. Macro level characteristics (i.e., context) can also constrain individual behaviour

7 (Dixon and Bruening, 2007) and thus the amount of time allocated to volunteering (Wicker

8 and Hallmann, 2013, Schlesinger and Nagel, 2013, Schlesinger and Nagel, 2016, Studer and

9 von Schnurbein, 2013). For instance, some volunteers might be more interested in

10 volunteering for mega events because of their reputation while others volunteer because of

11 their interest in the sport being played. Reputation and sport type provide the context in this

12 regard. Wicker and Hallmann (2013) identified the potential influence of macro-variables

13 such as institutional characteristics (e.g., type of organisation), financial resources, human

14 resource capacity, planning and development capacity, or infrastructure and resources

15 capacity. Empirically, Schlesinger and Nagel (2013) find that organisational variables such as

16 the structural conditions of the club or their policies influence the decision to volunteer.

17 People are more willing to volunteer for clubs in rural areas which indicates that clubs

18 located in rural areas might have a stronger community character or that there are fewer

19 leisure choices in rural areas (Schlesinger and Nagel, 2013). Growth-oriented policies impact

20 the decision to volunteer negatively, a feature which could be related to greater anonymity

21 within the club.

22 However, such macro level variables have not been investigated for their connection

23 with the time allocated to volunteering at sport events. However, there are several

24 'institutional characteristics' (Wicker and Hallmann, 2013) of an event such as the event's

25 status, duration, edition, number of athletes, number of sports played or the size of the 
1 destination the event is hosting that could be relevant. Indeed, some sport event literature has

2 introduced these characteristics to classify events (Stettler et al., 2010, Jago and Shaw, 1998,

3 Hallmann and Breuer, 2010, Getz, 1997).

4 Events can be classified as national or international events (i.e., being part of the

5 international federation's calendar and having international athletes/teams competing).

6 International events might offer a more exciting atmosphere and opportunities to experience

7 national pride (Ralston et al., 2004), both of which can induce volunteers to allocate more

8 time to those events. Moreover, the length of the event (i.e., one day vs. multiple days) is

9 likely to constrain the time allocated to volunteering. Multi-day events almost certainly

10 require more volunteer hours. Finally, the provenance of the event might also constrain the

11 allocation of time. Individuals might perceive that well-established events have greater

12 organisational capability and the opportunity costs associated with time allocated to

13 volunteering lower. The size of the destination as well as the number of competing athletes

14 and the number of sports (single sport events vs. multi-sport events) might also impact the

15 decision to allocate time to volunteering. These characteristics can influence the image of the

16 event which can influence decision-making when several alternatives exists (Ferrand, 1999).

17 The uniqueness of the event has been identified as a key motivated for event volunteers

18 (Dickson et al., 2014)

19 Reviewing the literature above, therefore, leads to a multi-level theoretical framework

20 presented in Figure 1 which is developed from Wicker and Hallmann (2013). The model

21 recognises that both individual and macro level factors might influence the time allocated to

22 volunteering, a claim which is now investigated empirically in the remainder of the paper.

23 Therefore we focus in particular on two exploratory objectives: (1) To determine which

24 individual level factors influence the decision to allocate time to volunteering and (2) to

25 identify which macro level factors influence the decision to allocate time to volunteering. 


\section{INSERT FIGURE 1}

\section{Methods and Data}

3 This study aimed to identify the general and common effects influencing the decision to

4 allocate time to volunteering at the individual and macro levels which requires a quantitative

5 research design. This was because the data are clustered by events, i.e. we deal with multiple

6 observations (Rabe-Hesketh and Skrondal, 2012).

\section{$7 \quad$ Measures}

8 For the dependent variable, participants were asked to indicate their time allocation to the

9 event in hours. For individual characteristics, data on working time (i.e., hours worked

10 including commute time) were collected using an open-ended question. Education levels

11 were converted into a binary variable (' 1 '=having at least a university entrance diploma/high

12 school certificate; $0=$ else). Income data categories were also converted to a binary variable

13 (i.e., affluent or not affluent) based on official statistics (DIW Berlin, 2010, Statistics New

14 Zealand, 2014). Education and income were converted into binary variables to enable a more

15 accurate comparison between countries, all of which had different education systems and

16 income levels. A small number of socio-demographic data were also collected, including

17 gender, age, and having children.

18 At the psychological level, motives captured preferences. The Volunteer Motivation

19 Scale for International Sporting Events ((VMS-ISE); Bang et al., 2008, Bang and

20 Chelladurai, 2009) was selected over other scales such as the Volunteer's Function Inventory

21 (Clary et al., 1998, Clary et al., 1992) or the Special Event Volunteer Motivation Scale

22 (Farrell et al., 1998) because it includes a love of sport dimension. MacLean and Hamm

23 (2007) showed that love of sport is important for volunteer's motivation. The six motivational

24 dimensions were expression of values (five items), interpersonal contacts (four items), career

25 orientation (five items), personal growth (four items), extrinsic rewards (two items), and love 
1 of sport (four items). In our use of the VMS-ISE, we excluded free food from the extrinsic

2 reward dimension, because volunteers in our sample were not always provided with free food

3 and we excluded the patriotism/community involvement construct as we had small-scale and

4 major events. All dimensions were measured using a five-point Likert Scale anchored by

5 strongly disagree (1) to strongly agree (5).

The macro level variables were based on secondary data. They included the binary

7 variables 'status' which indicated whether or not the event was part of the international

8 calendar of its federation and 'multi sports' which indicated whether the event was a single

9 sport event or a multi-sport event. The duration of the event was a metric variable as were the

10 edition of the event, number of athletes, and the host community population (see Table 1).

11 INSERT TABLE 1

12 Although several variables (e.g., socio-demographics) will be interpreted consistently

13 by researchers and respondents from different countries (MacInnes, 2006), interpretations

14 may vary for other variables. Therefore it was important to establish equivalence to ensure

15 consistent instrumentation (Lee and Jung, 2006). The original motivation scale was in

16 English (VMS-ISE) and was translated and back-translated into both German and Italian by

17 two independent researchers (Brislin, 1970). Pre-testing avoided construct bias (Lee and

18 Jung, 2006). The scales were pilot tested with 12 respondents, five in Germany and seven in

19 Italy. Some items were marginally reworded to increase the ease of understanding and

20 capture the intended meaning (Harkness and Schoua-Glusberg, 1998). Through using existing

21 validated measures, and using the common country and linguistic units and categories for

22 items, we achieved a high degree of comparability.

23 Sampling Procedures

24 We employed a convenience sampling approach. The events were chosen based on

25 accessibility. Data in Germany were collected from April 2011 to May 2014 at 21 different 
1 sport events. Access to the volunteers was always facilitated by the respective event owner.

2 Both online and paper-pencil questionnaires were used, depending on the preference of the

3 event owner. At two events (i.e., Paderborner Osterlauf and Hamburg Marathon), both

4 distribution methods were employed. We tested for demographic differences between both

5 methods but none were evident. In Italy, an online survey was distributed to volunteers of the

6 Winter Universiad held in Val di Fiemme in 2013. In New Zealand, data were collected using

7 an online survey from February to April 2015 at three different events. Table 2 presents an

8 overview of the events. Overall, the sample size was $n=2,302$.

9 INSERT TABLE 2

10 Data Analysis

11 Preceding the analysis, missing data were evaluated. There was no variable with missing data

12 exceeding $3 \%$ of observations. Missing data for the motivation variables were imputed using

13 regression analysis. Additive indices were created for each motivational dimension as the

14 dimensions have been validated in previous literature (Bang et al., 2008, Bang and

15 Chelladurai, 2009, Hallmann and Harms, 2012, Wang and Wu, 2014). Cronbach's Alpha

16 varied between .714 to .863 (Values $\alpha=.714$; Interpersonal $\alpha=.863$; Career $\alpha=.858$; Growth

$17 \alpha=.781$; Extrinsic $\alpha=.718$; Love of Sport $\alpha=.844$ ).

18 Multi-level modelling was employed because the data were nested into groups (i.e.,

19 the participants were volunteers at different events). The underlying assumption was that

20 macro level effects (i.e., external to the individual) can influence the individual's behaviour.

21 This implied that multi-level modelling should be applied because, for example, standard

22 regression variances do not account for the error decomposition that is implied in having

23 repeated observations on a higher level unit (Tabachnick and Fidell, 2007) and standard

24 errors can be biased (Cameron and Miller, 2015). ${ }^{1}$ Tabachnick and Fidell (2007) emphasized

25 that large sample sizes are required to conduct multi-level modelling ( $>20$ cases at the higher 
1 level). Besides the absolute number of cases at the macro level, the number of cases per event

2 was also important (O'Connell and McCoach, 2008). Although some authors recommend 30

3 cases per level (Snijders and Bosker, 1999), depending on effect sizes, power, and the

4 modelling approach, the sample size can be as low as nine, 'if one is willing to accept a

5 standard error that is five percent higher than this minimum' (Snijders and Bosker, 1999,

6 p.150). Summing up, we were not, by design, interested in exploring the differences between

7 events. Our focus was the factors influencing the time allocated to volunteering at events

8 generally.

9 Results

10 The time allocated to volunteering averaged 39 hours per event. The majority of volunteers

11 across all sport events were women (62\%). The mean age of the volunteers was 32 years. The

12 mean working time of the volunteers was 33 hours. Based on income only $11 \%$ of the sample

13 could be described as affluent (remembering that we measure income as a binary variable -

14 see Table 1). Of the respondents, $26 \%$ had children. The connection to sports and

15 volunteering was high, with $84 \%$ indicating that they participate in any sport weekly. Most of

16 the participants (i.e., 70\%) had previous volunteer experience. The summary statistics are

17 displayed in Table 3.

18 INSERT TABLE 3

19 The model was tested for multicollinearity using the Variance Inflation Factor (VIF).

20 Multi-collinearity was not an issue because no VIF was higher than 3 (Hair et al., 2010).

21 White's General Test for Heteroscedasticity also revealed no concerns $\left(\chi^{2}(214)=215.34,201\right.$,

$22 \mathrm{p}=.882$ ). Using multi-level modeling, initially an intercept-only (or null) model (a model

23 without any independent variables) was estimated. This is compared to a null (intercept-only)

24 model to test the significance of event effects by means of a likelihood ratio test. It was

25 calculated as two times the difference in the log likelihood values for two models. The result 
$1 \quad(2 *(-11,667.526-12,045.87)=756.688$ on one degree of freedom $)$ was significant suggesting

2 that events are associated with the number of hours volunteered. The appropriateness of the

3 multi-level approach was also supported by an intraclass correlation of .264. This exceeded

4.05 suggesting that the simultaneous estimation of individual and context variables is

5 appropriate (Hox, 2002). Thereafter, a full multi-level model with individual and event

6 variables was estimated

$7 \quad \mathrm{R}^{2}$ at the individual level amounted to $21.76 \%$ and at the macro level to $73.28 \%$.

8 Gender $(\beta=-5.193)$ was the only individual level variable which had a significant impact on

9 hours volunteered. Of the macro level variables, local population $(\beta=-.00001)$, status

$10 \quad(\beta=31.000)$, and duration $(\beta=2.437)$ served as significant predictors for hours volunteered.

11 Table 4 displays the multi-level model.

12 INSERT TABLE 4

\section{Discussion and Conclusion}

14 This research provides a more nuanced examination of volunteers by focusing on the amount

15 of time a volunteer is prepared to allocate to a sport event in the context of examining the role

16 of macro-level event factors on the decision to volunteer. The focus was thereby to determine

17 common effects of individual and macro level characteristics controlling for event

18 heterogeneity. This is the first paper applying a multi-level model for sport event

19 volunteering.

20 The results indicate that the model provides a significant prediction of hours

21 volunteered and that variables at the individual and macro level are significant predictors of

22 time allocated to volunteering. At the individual level, gender was the sole significant

23 variable whereas at the macro level, the variables local population, status, and duration were

24 significant. Therefore, it seems that event characteristics are capturing previous significant

25 individual effects. 
1 Considering gender, our research is consistent with previous findings and theory that

2 males contribute significantly more time than females (Dawson and Downward, 2013, Taylor

3 et al., 2012). However, we can add that the effects are stable irrespective of the event. One

4 explanation for this finding is that although the majority of volunteers are female, they still

5 have more commitments (e.g., child care) than males. The results at the macro level cannot

6 be compared with previous findings because this is the first study to include macro event

7 variables as determinants of time allocation at sport events controlling for events. The local

8 population had a significant, but small, negative effect on hours volunteered. One reason for

9 this finding could be that life in larger communities is often more anonymous, thus mitigating

10 an individual's willingness to contribute time to event volunteering. In this respect a weaker

11 sense of community ('communitas') may weaken the potential to foster social capital that is

12 expressed in volunteering (Chalip, 2006, p.111). Thus, opposite relationships seem to be

13 more prevalent in smaller communities. This corresponds to the finding by Kristiansen et al.

14 (2015) who found a strong sense of community as key driver for volunteer retention. It might

15 be easier to achieve a sense of community in smaller communities. However, the effect was

16 relatively small.

17 There was a positive effect of an event's international status on time allocation. This

18 could be related to the self-identity of the volunteer; the volunteer wants to be affiliated with

19 the event which enriches them personally; and the volunteer might assume that an

20 international event has more potential in this regard. This reflects to some degree the findings

21 of Kristiansen et al. (2014) who found that the target group of the event looks for certain

22 motivations to be accomplished. This leads to certain interrelationships of event

23 characteristics and individual characteristics. It is not surprising that as the duration of the

24 event increases, the hours volunteered also increase significantly. If an event's duration is 
1 longer, more volunteer hours are needed. In the absence of having to volunteer for specific

2 durations, this could also show that that longer duration events elicit greater commitment.

\section{Theoretical, Methodological, and Practical Contributions}

4 This study has advanced our understanding of volunteers in a number of ways. Overall, our

5 investigation considered volunteering in the context of decision-making theory, rooted in the

6 neoclassical economic theory of behaviour (Angner, 2012). The inclusion of motivation and

7 context (i.e. macro level variables) necessitated a shift towards accepting insights from

8 behavioural economics (Burgham and Downward, 2005, Wicker and Hallmann, 2013,

9 Emrich et al., 2012, Dawson and Downward, 2013, Schlesinger and Nagel, 2013, Hallmann,

10 2015). Including macro level characteristics in the model proved insightful as the results

11 clearly suggest that it is not only individual characteristics that influence decision-making.

12 This finding complements previous macro-variable research conducted with sport club

13 volunteers (Schlesinger and Nagel, 2013). Moreover, the findings suggest that macro level

14 variables matter more than individual level variables within the decision-making process to

15 allocate time to volunteering. This is indicated by the higher $\mathrm{R}^{2}$ at the macro level. Therefore

16 this paper provides a platform for additional research into the macro level variables that

17 impact the allocation of a volunteer's time. This finding also has practical implications

18 because context (i.e. event characteristics) can be steered by event managers.

19 There are some practical implications for event managers. The first is that managers

20 of international sports events should stress the international status of the event because it

21 increases the time allocated to the event. Having motivated volunteers within the workforce

22 will likely increase the quality of the volunteer's service delivery. If events are not

23 international themselves, then links to international competition or event status could be

24 reinforced. It may also be the case that event managers could focus on attracting male

25 volunteers as recruiting them will increase the number of people willing to volunteer for 
1 longer hours. More fundamentally, it might be that job-tasks need to be designed such that

2 shorter duration activities can be dove-tailed together to greater facilitate current patterns of

3 female volunteering.

$4 \quad$ Limitations and Future Research

5 There are a number of limitations to the research. It would have been ideal having the

6 opportunity to investigate similar events of a more balanced number in and across all (and

7 ideally more) countries (e.g. three running events, three equestrian events, three tennis events

8 and three triathlon events plus several multi-sport events in each country). This is because the

9 type of sport matters for volunteering (Hallmann and Harms, 2012). However, this was not

10 possible for pragmatic reasons and we controlled for the events.

11 Although we carefully managed potential measurement issues across the three

12 countries using multi-level modelling, bias is certainly possible. We carefully selected the

13 events in New Zealand and Italy to ensure comparability to some of the German events.

14 Another useful approach for future research is to include not only scales but also self-

15 assessment components to control for country effects (King et al., 2004).

16 Future research should include more and other independent variables such as

17 involvement with the sport that is played/practiced at the event (looking at single-sport

18 events) or whether peers (family and friends) are also part of the volunteer workforce. We

19 acknowledge that previous research identified that volunteering can stand for a shared

20 lifestyle in communities (Kristiansen et al., 2015) and a lot of interaction with peers who also

21 volunteer. Nonetheless, we suggest including this into future quantitative research to control

22 for further event heterogeneity. As there are differences between episodic and continuous

23 volunteering (Holmes, 2014), previous experience should also capture this which was not the

24 case in our research. We focused on a single binary variable for previous experience. We also

25 suggest integrating perceptions of the local culture on the individual level - some insights 
1 have been already provided by qualitative studies (Randle and Dolnicar, 2009, Hoeber, 2010)

2 - and destination attributes on the macro level into future quantitative research. It might be

3 useful to conduct research about the extent to which volunteers perceive a moral obligation to

4 volunteer because the event hosted concerned their 'beloved sport'. The extent to which

5 volunteers might want to promote their destination might be also an interesting variable for

6 future studies. In general, more comparative research is needed to fully understand the

7 underlying drivers of time allocation by volunteers to different types of events. 


\section{$1 \quad$ Footnotes}

$2{ }^{1}$ While the multi-level approach is the correct procedure to use with hierarchical data

3 when focusing on the higher-level coefficients, problems arise if sample sizes at the macro

4 level are small. Having 25 cases at the second level is appropriate. However, the results are

5 robust as we also estimated an OLS model with cluster-corrected standard errors and

6 obtained similar results.

7 


\section{References}

Alexander, A.Kim, S.-B. and Kim, D.-Y. (2015), "Segmenting volunteers by motivation in the 2012 London Olympic Games". Tourism Management, Vol. 47 No. Supplement C, pp. 1-10.

Altman, M. (2006), Introduction. In: ALTMAN, M. (ed.) Handbook of Contemporary Behavioral Economics: Foundations and Developments. M. E. Sharpe, Amonk, NY. Angner, E. (2012), A course in behavioral economics, Palgrave Macmillan, New York, NY. Apinunmahakul, A.Barham, V. and Devlin, R. A. (2009), "Charitable Giving, Volunteering, and the Paid Labor Market". Nonprofit and Voluntary Sector Quarterly, Vol. 38 No. 1, pp. 77-94.

Bang, H.Alexandris, K. and Ross, S. D. (2008), "Validation of the revised Volunteer Motivations Scale for International Sporting Events (VMS-ISE) at the Athens 2004 Olympic Games". Event Management, Vol. 12 No. 3-4, pp. 119-131.

Bang, H. and Chelladurai, P. (2009), "Development and validation of the volunteer motivations scale for international sporting events (VMS-ISE)". International Journal of Sport Management and Marketing, Vol. 6 No. 4, pp. 332-350.

Bauer, T. K.Bredtmann, J. and Schmidt, C. M. (2013), "Time vs. money — The supply of voluntary labor and charitable donations across Europe". European Journal of Political Economy, Vol. 32 No. 0, pp. 80-94.

Becker, G. S. (1965), "A theory of the allocation of time". The Economic Journal, Vol. 75 No. 3, pp. 493-517.

Becker, G. S. (1991), A treatise on the family, Harvard University Press, Cambridge, MA.

Brislin, R. W. (1970), "Back-Translation for Cross-Cultural Research". Journal of CrossCultural Psychology, Vol. 1 No. 3, pp. 185-216.

Brown, E. and Lankford, H. (1992), "Gifts of money and gifts of time: Estimating the effects of tax prices and available time". Journal of Public Economics, Vol. 47 No. 3, pp. 321-341.

Burgham, M. and Downward, P. (2005), "Why volunteer, time to volunteer? A case study from swimming". Managing Leisure, Vol. 10 No. 2, pp. 79-93.

Cameron, A. C. and Miller, D. L. (2015), "A Practitioner's Guide to Cluster-Robust Inference". Journal of Human Resources, Vol. 50 No. 2, pp. 317-372.

Cappellari, L.Ghinetti, P. and Turati, G. (2011), "On time and money donations". The Journal of Socio-Economics, Vol. 40 No. 6, pp. 853-867.

Chalip, L. (2006), "Towards Social Leverage of Sport Events". Journal of Sport \& Tourism, Vol. 11 No. 2, pp. 109-127.

Clary, E. G.Snyder, M. and Ridge, R. D. (1992), "Volunteers' motivations: A functional strategy for the recruitment, placement, and retention of volunteers". Nonprofit Management and Leadership, Vol. 2 No. 4, pp. 333-350.

Clary, E. G.Snyder, M.Ridge, R. D.Copeland, J.Stukas, A. A.Haugen, J. and Miene, P. (1998), "Understanding and Assessing the Motivations of Volunteers: A Functional Approach". Joumal of Personality and Social Psychology, Vol. 74 No. 6, pp. 15161530.

Collignon, H. and Nicolas, S. (2014). "Winning in the business of sport" [Online]. Paris and Doha. Available: https://www.atkearney.co.uk/documents/10192/5258876/Winning+in+the+Business+ of+Sports.pdf/ed85b644-7633-469d-8f7a-99e4a50aadc8 [accessed 04.01.2018. 
Cuskelly, G.Hoye, R. and Auld, C. (2006), Working with volunteers in sport. Theory and practice, Routledge, Abington.

Dawson, P. and Downward, P. (2013), "The Relationship Between Participation in Sport and Sport Volunteering: An Economic Analysis". International Journal of Sport Finance, Vol. 8, pp. 75-92.

Dickson, T. J.Benson, A. M. and Terwiel, F. A. (2014), "Mega-event volunteers, similar or different? Vancouver 2010 vs London 2012". International Journal of Event and Festival Management, Vol. 5 No. 2, pp. 164-179.

Diw Berlin (2010). "Einkommensentwicklung in Deutschland: Die Mittelschicht verliert" [Online]. Berlin: German Institute for Economic Research. Available: http://www.diw.de/de/diw 01.c.357516.de/themen_nachrichten/einkommensentwickl ung in deutschland die mittelschicht verliert.html [accessed 04.03.2015.

Dixon, M. A. and Bruening, J. E. (2007), "Work-family conflict in coaching I: A top-down perspective". Journal of Sport Management, Vol. 21 No. 3, pp. 377-406.

Emrich, E.Pitsch, W.Flatau, J. and Pierdzioch, C. (2012), "Voluntary engagement in sports clubs: A behavioral model and some empirical evidence". International Review for the Sociology of Sport.

Farrell, J. M.Johnston, M. E. and Twynam, D. G. (1998), "Volunteer motivation, satisfaction, and management at an elite sporting competition". Journal of Sport Management, Vol. 12 No. 4, pp. 288-300.

Ferrand, A. (1999), "Sponsorship as a reinforcement factor of sponsor brand image". European Journal For Sport Management, Vol. 6 No. 2, pp. 48-68.

Flatau, J.Emrich, E. and Pierdzioch, C. (2012), Zum zeitlichen Umfang ehrenamtlichen Engagements in Sportvereinen - Sozioökonomische Modellbildung und empirische Prüfung. Hambug: University of Hamburg, Department of Economics (Working paper series No. 122).

Frey, B. S. (2000), Not just for the money. An economic theory of personal motivation, Edward Elgar Publishing, Cheltenham.

Fudenberg, D. (2006), "Advancing beyond Advances in behavioral economics". Journal of Economic Literature, Vol. 44 No. September, pp. 694-711.

Getz, D. (1997), Event management \& Event tourism, Cognizant Communication Corporation, Elmsford, NY.

Hair, J. F.Black, W. C.Babin, B. J. and Anderson, R. E. (2010), Multivariate data analysis. A global perspective, Pearson, Upper Saddle River.

Hallmann, K. (2015), "Modelling the decision to volunteer in organised sports". Sport Management Review, Vol. 18 No. 3, pp. 448-463.

Hallmann, K. and Breuer, C. (2010), "Image Fit between Sport Events and their Hosting Destinations from an Active Sport Tourist Perspective and its Impact on Future Behaviour.". Journal of Sport \& Tourism, Vol. 15 No. 3, pp. 211-233.

Hallmann, K. and Harms, G. (2012), "Determinants of volunteer motivation and their impact on future voluntary engagement: A comparison of volunteer's motivation at sport events in equestrian and handball". International Journal of Event and Festival Management, Vol. 3 No. 3, pp. 272-291.

Harkness, J. A. and Schoua-Glusberg, A. (1998), "Questionnaires in translation". ZUMANachrichten Spezial: Cross-Cultural Survey Equivalence, Vol. 3, pp. 87-126.

Hiltrop, J.-M. (1999), "The quest for the best: human resource practices to attract and retain talent". European Management Journal, Vol. 17 No. 4, pp. 422-430.

Hoeber, L. (2010), "Experiences of volunteering in sport: Views from Aboriginal individuals". Sport Management Review, Vol. 13 No. 4, pp. 345-354. 
Holbrook, M. B. and Lehmann, D. R. (1981), "Allocating Discretionary Time: Complementarity among Activities". Journal of Consumer Research, Vol. 7 No. 4, pp. 395-406.

Holmes, K. (2014), "'It fitted in with our lifestyle': an investigation into episodic volunteering in the tourism sector". Annals of Leisure Research, Vol. 17 No. 4, pp. 443-459.

Hox, J. J. (2002), Multilevel analysis: Techniques and applications, Lawrence Erlbaum, Mahwah, NJ.

Ingerson, L. (2001), A comparison of the economic contribution of hallmark sporting and performing arts events. In: GRATTON, C. \& HENRY, I. (eds.) Sport in the city. The role of sport in exonomic and social regeneration. Routledge, London and New York.

Iso-Ahola, S. E. (1989), Motivation for leisure. In: JACKSON, E. L. \& BURTON, T. L. (eds.) Understanding leisure and recreation. Mapping the past, chartering the future. Venture Publishing, Inc, Oxford Circle.

Jago, L. and Shaw, R. N. (1998), "Special events: A conceptual and definitional framework". Festival Management \& Event Tourism, Vol. 5 No. 1-2, pp. 21-32.

Kahneman, D.Wakker, P. P. and Sarin, R. (1997), "Back to Bentham? Explorations of experienced utility". The Quarterly Journal of Economics, Vol. 112 No. 2, pp. 375406.

Kim, E. and Cuskelly, G. (2017), "A Systematic Quantitative Review Of Volunteer Management in Events". Event Management, Vol. 21 No. 1, pp. 83-100.

King, G.Murray, C. J. L.Salamon, J. A. and Tandon, A. (2004), "Enhancing the validity and cross-cultural comparability of measurement in survey research". American Political Science Review, Vol. 98 No. 1, pp. 191-207.

Klein, G. A.Calderwood, R. and Clinton-Cirocco, A. (1986), Rapid decision making on the fireground. In: SOCIETY, H. F. A. E. (ed.) Proceedings of the Human Factors and Ergonomics Society 30th Annual Meeting. Ablex, Norwood, NJ.

Kodama, E.Doherty, A. and Popovic, M. (2013), "Front line insight: an autoethnography of the Vancouver 2010 volunteer experience". European Sport Management Quarterly, Vol. 13 No. 1, pp. 76-93.

Kristiansen, E.Skille, E. A. and Hanstad, D. V. (2014), "From community basaed identities to individual benefits for volunteers". Scandinavian Sport Studies Forum, Vol. 5, pp. 4768.

Kristiansen, E.Skirstad, B.Parent, M. M. and Waddington, I. (2015), "'We can do it': Community, resistance, social solidarity, and long-term volunteering at a sport event". Sport Management Review, Vol. 18 No. 2, pp. 256-267.

Lee, J. and Jung, D. (2006), "Measurement issues across different cultures.". Journal of Korean Academy of Nursing, Vol. 69 No. 8, pp. 1295-1300.

Macinnes, J. (2006), "Category and Comparison Across What Kind of Frontier?". ZUMANachrichten Spezial: Conducting cross-national and cross-cultural surveys. Papers from the 2005 Meeting of the International Workshop on Comparative Survey Design and Implementation (CSDI), Vol. 12, pp. 101-114.

Maclean, J. and Hamm, S. (2007), "Motivation, commitment, and intentions to volunteers at a large Candian sporting event". Leisure/Loisir, Vol. 31 No. 2, pp. 523-556.

Mulder, M. R.Rapp, J. M.Hamby, A. and Weaver, T. (2015), "Consumer transformation through volunteer service experiences". The Service Industries Journal, Vol. 35 No. 15-16, pp. 865-882.

O'connell, A. A. and Mccoach, D. B. (2008), Multi-level modeling of educational data, Information Age Publishing, Charlotte, NC. 
Rabe-Hesketh, R. and Skrondal, A. (2012), Multilevel and longitudinal modeling using Stata, Stata Press, College Station, TX.

Ralston, R.Downward, P. and Lumsdon, L. (2004), "The Expectations of Volunteers Prior to the XVII Commonwealth Games, 2002: A Qualitative Study". Event Management, Vol. 9 No. 1/2, pp. 13-26.

Randle, M. J. and Dolnicar, S. (2009), "Does cultural background affect volunteering behavior?". Journal of Nonprofit and Voluntary Sector Marketing, Vol. 21 No. 2, pp. 225-247.

Roza, L.Shachar, I.Meijs, L. and Hustinx, L. (2017), "The nonprofit case for corporate volunteering: a multi-level perspective". The Service Industries Journal, Vol. 37 No. 11-12, pp. 746-765.

Schlesinger, T. and Nagel, S. (2013), "Who will volunteer? Analysing individual and structural factors of volunteering in Swiss sports clubs". European Journal of Sport Science, Vol. 13 No. 6, pp. 707-715.

Schlesinger, T. and Nagel, S. (2016), "Individual and contextual determinants of stable volunteering in sport clubs". International Review for the Sociology of Sport.

Shank, M. D. (2009), Sports marketing. A strategic perspective, Pearson Education, Upper Saddle River.

Simonson, I. and Tversky, A. (1992), "Choice in context: Tradeoff contrast and extremeness aversion". Journal of Marketing Research, Vol. 29 No. 3, pp. 281-295.

Skille, E. A. and Hanstad, D. V. (2013), "Who are they and why do they do it? The habitus of sport event volunteers in Norway: volunteers at the European handball championship for women 2010". Sport in Society, Vol. 16 No. 9, pp. 1135-1148.

Skirstad, B. and Hanstad, D. V. (2013), "Gender matters in sport event volunteering". Managing Leisure, Vol. 18 No. 4, pp. 316-330.

Snijders, T. and Bosker, R. (1999), Multilevel analysis - An introduction to basic and advanced multilevel modeling, Sage Publications, London.

Statistics New Zealand (2014). "New Zealand income survey: June 2014 quarter" [Online]. Available: http://www.stats.govt.nz/browse for stats/income-andwork/Income/NZIncomeSurvey HOTPJun14qtr.aspx [accessed 12.03.2015.

Stettler, J.Caliesch, D. and Herzer, C. (2010), Methodenevaluation des Forschungsprojekts „UEFA EURO 2008TM und Nachhaltigkeit" und methodische Erweiterung der Event-Scorecard zur Messung der volkswirtschaftlichen Effekte von Sportgrossevents Luzern: Institut für Tourismuswirtschaft ITW. Hochschule Luzern - Wirtschaft.

Studer, S. and Von Schnurbein, G. (2013), "Organizational Factors Affecting Volunteers: A Literature Review on Volunteer Coordination". VOLUNTAS: International Journal of Voluntary and Nonprofit Organizations, Vol. 24 No. 2, pp. 403-440.

Tabachnick, B. G. and Fidell, L. S. (2007), Using multivariate statistics, Allyn \& Bacon, Boston, MA.

Taylor, P. D.Panagouleas, T. and Nichols, G. (2012), "Determinants of sports volunteering and sports volunteer time in England". International Journal of Sport Policy and Politics, Vol. 4 No. 2, pp. 201-220.

Tversky, A. and Kahneman, D. (1971), "Belief in the law of small numbers.

Psychological Bulletin, 76,

105-110". Psychological Bulletin, Vol. 76 No. 2, pp. 105-110.

Wang, C. and Wu, X. (2014), "Volunteers' motivation, satisfaction, and management in large-scale events: An empirical test from the 2010 Shanghai World Expo". Voluntas: International Journal of Voluntary and Nonprofit Organizations, Vol. 25 No. 3, pp. 754-771. 
Wicker, P. (2017, in press), "Volunteerism and volunteer management in sport". Sport Management Review.

Wicker, P. and Hallmann, K. (2013), "A multi-level framework for investigating the engagement of sport volunteers". European Sport Management Quarterly, Vol. 13 No. 1, pp. 110-139.

Wollebæk, D.Skirstad, B. and Hanstad, D. V. (2014), "Between two volunteer cultures: Social composition and motivation among volunteers at the 2010 test event for the FIS Nordic World Ski Championships". International Review for the Sociology of Sport, Vol. 49 No. 1, pp. 22-41.

Ziemek, S. (2006), "Economic analysis of volunteer's motivations - A cross-country study". The Journal of Socio-Economics, Vol. 35 No. 3, pp. 532-555. 
Table 1.Overview of variables.

\begin{tabular}{|c|c|c|}
\hline Variable & Description & Scale \\
\hline \multicolumn{3}{|l|}{ Time allocation } \\
\hline Time & Hours the volunteer worked at the event. & Metric \\
\hline \multicolumn{3}{|c|}{ Economic and socio-demographic variables } \\
\hline Income & $\begin{array}{l}\text { Being affluent based on individual monthly net } \\
\text { income (For the German and Italian sample, a cut } \\
\text { was made at EUR 2,500 monthly net income; } 0=\text { not } \\
\text { being affluent and earning EUR 2,500 or less, } \\
1=\text { being affluent and earning at least EUR 2,501; } \\
\text { For the New Zealand sample, a cut was made at } \\
\text { NZD 50,000 yearly net income; } 0=\text { not being } \\
\text { affluent and earning NZD 50,000 or less, } 1=\text { being } \\
\text { affluent and earning at least NZD 50,001 or more) }\end{array}$ & Dummy \\
\hline Work time & How many hours do you work weekly? & Metric \\
\hline Education & $\begin{array}{l}\text { Highest educational level attained }(1=\text { at least } A- \\
\text { levels/university entrance diploma, } 0=\text { else })\end{array}$ & Dummy \\
\hline Gender & Gender of the participant $(1=$ female, $0=$ male $)$ & Dummy \\
\hline Age & Age in years & Metric \\
\hline Nationality & $\begin{array}{l}\text { Nationality of the respondent }(1=\text { country of data } \\
\text { collection; i.e. Germany, Italy or New Zealand; } \\
0=\text { else) }\end{array}$ & Dummy \\
\hline Children & Having children $(1=y e s ; 0=n o)$ & Dummy \\
\hline Psychological & 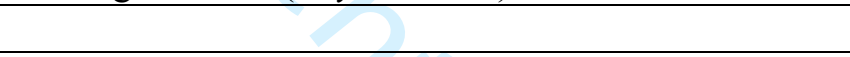 & \\
\hline \multicolumn{3}{|c|}{$\begin{array}{l}\text { Volunteer motivation (five-point Likert scales: from } 1=\text { strongly disagree to } 5=\text { strongly } \\
\text { agree) }\end{array}$} \\
\hline Values1 & I want to help out in any capacity. & Ordinal \\
\hline Values2 & I want to do something worthwhile. & Ordinal \\
\hline Values3 & I feel it is important to help others. & Ordinal \\
\hline Values4 & I want to make the event a success. & Ordinal \\
\hline Values5 & Volunteering creates a better society. & Ordinal \\
\hline Interpersonal1 & I want to interact with others. & Ordinal \\
\hline Interpersonal2 & I want to work with different people. & Ordinal \\
\hline Interpersonal3 & I want to meet people. & Ordinal \\
\hline Interpersonal4 & I want to develop relationships with others. & Ordinal \\
\hline Career 1 & $\begin{array}{l}\text { Volunteering experience will look good on my } \\
\text { resume. }\end{array}$ & Ordinal \\
\hline Career2 & I want to gain some practical experiences. & Ordinal \\
\hline Career3 & $\begin{array}{l}\text { I can make new contacts that might help my } \\
\text { business or career. }\end{array}$ & Ordinal \\
\hline Career4 & I want to gain work-related experience. & Ordinal \\
\hline Career5 & $\begin{array}{l}\text { I want to gain experience that would be beneficial in } \\
\text { any job. }\end{array}$ & Ordinal \\
\hline Growth1 & Volunteering makes me feel needed. & Ordinal \\
\hline Growth2 & I can explore my own strengths. & Ordinal \\
\hline Growth3 & Volunteering makes me feel important. & Ordinal \\
\hline Growth4 & $\begin{array}{l}\text { Volunteering allows me to gain a new perspective } \\
\text { on things. }\end{array}$ & Ordinal \\
\hline Extrinsic 1 & I want to get event uniforms/licensed products & Ordinal \\
\hline Extrinsic2 & I want to get tickets/free admission & Ordinal \\
\hline
\end{tabular}




\begin{tabular}{|c|c|c|}
\hline Variable & Description & Scale \\
\hline Sport1 & I like any event related to sport. & Ordinal \\
\hline Sport2 & $\begin{array}{l}\text { I like any event related to this sport (e.g. triathlon, } \\
\text { golf, etc.). }\end{array}$ & Ordinal \\
\hline Sport3 & Sport is something I love. & Ordinal \\
\hline Sport4 & I enjoy being involved in sport activities. & Ordinal \\
\hline Experience & $\begin{array}{l}\text { Any previous sport volunteering experience }(1=y e s \text {, } \\
0=n o)\end{array}$ & Dummy \\
\hline Sport Participation & Weekly sport participation $(1=$ yes, $0=n o)$ & Dummy \\
\hline \multicolumn{3}{|c|}{ Macro level variables } \\
\hline Status & $\begin{array}{l}\text { Part of the federation's international calendar } \\
(1=\text { yes; } 0=n o)\end{array}$ & Dummy \\
\hline Duration & Duration of the event & Metric \\
\hline Edition & Edition of the event & Metric \\
\hline Multi Sports & $\begin{array}{l}\text { Type of sport event ( } 1=\text { multi-sport event; } 0=\text { single } \\
\text { sport event })\end{array}$ & Dummy \\
\hline Local population & Number of people living in the host community & Metric \\
\hline Athletes & Number of athletes competing & Metric \\
\hline
\end{tabular}


Table 2. Overview of events.

\begin{tabular}{|c|c|c|c|}
\hline Event & Country & $\begin{array}{l}\text { Year of data } \\
\text { collection }\end{array}$ & Multi-Sports \\
\hline EHF Final 4 & GER & 2011 & Single Sport (Handball) \\
\hline CHIO Aachen & GER & 2011 & Single Sport (Equestrian) \\
\hline Wake the line & GER & 2013 & $\begin{array}{l}\text { Single Sport } \\
\text { (Wakeboard) }\end{array}$ \\
\hline Race for the Cure & GER & 2013 & Single Sport (Athletics) \\
\hline Ahrathon & GER & 2013 & Single Sport (Triathlon) \\
\hline Come Together Cup & GER & 2013 & Single Sport (Football) \\
\hline Triathlon Forchheim & GER & 2013 & Single Sport (Triathlon) \\
\hline Triathlon Siegburg & GER & 2013 & Single Sport (Triathlon) \\
\hline Winter Universiad Val di Fiemme & ITA & 2013 & Multi Sports \\
\hline National Special Olympics & GER & 2014 & Multi Sports \\
\hline Schliersee Triathlon & GER & 2013 & Single Sport (Triathlon) \\
\hline Ironman Berlin & GER & 2013 & Single Sport (Triathlon) \\
\hline Chiemsee Triathlon & GER & 2013 & Single Sport (Triathlon) \\
\hline Frankfurt City Triathlon & GER & 2013 & Single Sport (Triathlon) \\
\hline Cologne Triathlon & GER & 2013 & Single Sport (Triathlon) \\
\hline Erlangen Triathlon & GER & 2013 & Single Sport (Triathlon) \\
\hline Borken Triathlon & GER & 2013 & Single Sport (Triathlon) \\
\hline Paderborner Osterlauf & GER & 2014 & Single Sport (Athletics) \\
\hline Hamburg Marathon & GER & 2014 & Single Sport (Athletics) \\
\hline International German Gymnastics & GER & 2013 & \\
\hline Festival & & & \\
\hline Rund um Köln & GER & 2014 & Single Sport (Cycling) \\
\hline EHF Final Four & GER & 2014 & Single Sport (Handball) \\
\hline New Zealand Masters Games & NZL & 2015 & Multi Sports \\
\hline Volvo Ocean Race & NZL & 2015 & Single Sports (Sailing) \\
\hline $\begin{array}{l}\text { Holden PGA New Zealand } \\
\text { Championships }\end{array}$ & NZL & 2015 & Single Sports (Golf) \\
\hline
\end{tabular}


Table 3. Summary statistics based on mean values and for binary variables as sample proportions.

\begin{tabular}{lllll}
\hline Variable & Mean value & $\begin{array}{l}\text { Standard } \\
\text { deviation }\end{array}$ & $\begin{array}{l}\text { Minimum } \\
\text { value }\end{array}$ & $\begin{array}{l}\text { Maximum } \\
\text { value }\end{array}$ \\
\hline Individual variables & & & & 792 \\
\hline Time & 39.842 & 45.334 & 1 & 1 \\
Income (being & .111 & .314 & 0 & 80 \\
affluent) & & & & 1 \\
Work time & 33.105 & 16.521 & 0 & 1 \\
Education & .456 & .498 & 0 & 85 \\
Gender & .618 & .486 & 0 & 1 \\
Age & 32.603 & 16.220 & 12 & 1 \\
Nationality & .929 & .257 & 0 & 5 \\
Children & .262 & .440 & 0 & 5 \\
Values Index & 4.343 & .544 & 1.4 & 5 \\
Interpersonal Index & 3.994 & .781 & 1 & 5 \\
Career Index & 3.322 & .977 & 1 & 5 \\
Growth Index & 3.501 & .813 & 1 & 5 \\
Extrinsic Index & 1.978 & 1.026 & 1 & 1 \\
Love of Sport Index & 3.841 & .860 & 1 & 1 \\
Experience & .701 & .458 & 0 & 1 \\
Sport Participation & .841 & .366 & 0 & 20 \\
\hline Macro level variables & & & & 98 \\
\hline Status & .516 & .500 & 0 & $3,502,000$ \\
Duration & 5.801 & 4.192 & 1 & 50,000 \\
Edition & 23.231 & 22.219 & 1 &
\end{tabular}


Table 4. Results of regression analyses using time allocated to volunteering as dependent variable (displayed are the coefficients).

\begin{tabular}{|c|c|c|}
\hline 8 & $\begin{array}{l}\text { Model 1a (intercept only } \\
\text { model) }\end{array}$ & Model 1b (full model) \\
\hline Income (being affluent) & & .369 \\
\hline Work time & & -.002 \\
\hline Education & & 1.613 \\
\hline Gender & & $-5.193 *$ \\
\hline Age & & -.063 \\
\hline Nationality & & 1.323 \\
\hline Children & & -2.033 \\
\hline Values Index & & 3.196 \\
\hline Interpersonal Index & & .499 \\
\hline Career Index & & .363 \\
\hline Growth Index & & .523 \\
\hline Extrinsic Index & & -.164 \\
\hline Love of Sport Index & & -1.845 \\
\hline Experience & & 3.159 \\
\hline Sport Participation & & 2.994 \\
\hline Status & & $31.000 * * *$ \\
\hline Duration & & $2.437 * * *$ \\
\hline Edition & & -.144 \\
\hline Multi Sports & & 11.654 \\
\hline Local population & & $-.00001 * * *$ \\
\hline Athletes & & -.00004 \\
\hline \multirow[t]{2}{*}{ Constant/Intercept } & $31.257 * * *$ & 7.988 \\
\hline & - & $\chi^{2}: 108.73 * * *$ \\
\hline Variance individual level: & $1,435.769$ & $1,556.231$ \\
\hline \multirow[t]{2}{*}{ Variance event level: } & 516.526 & 75.456 \\
\hline & & $\begin{array}{l}\mathrm{R}^{2} \text { individual level: } \\
21.76 \%{ }^{\#} \\
\mathrm{R}^{2} \text { event level }: 73.28 \%\end{array}$ \\
\hline Intraclass Correlation & .265 & $.046^{\# \#}$ \\
\hline $\mathrm{n}$ & 2,302 & 2,302 \\
\hline
\end{tabular}


Figure 1. Theoretical model: Three-level model with individual and macro level characteristics influencing the decision to allocate time to sport event volunteering.

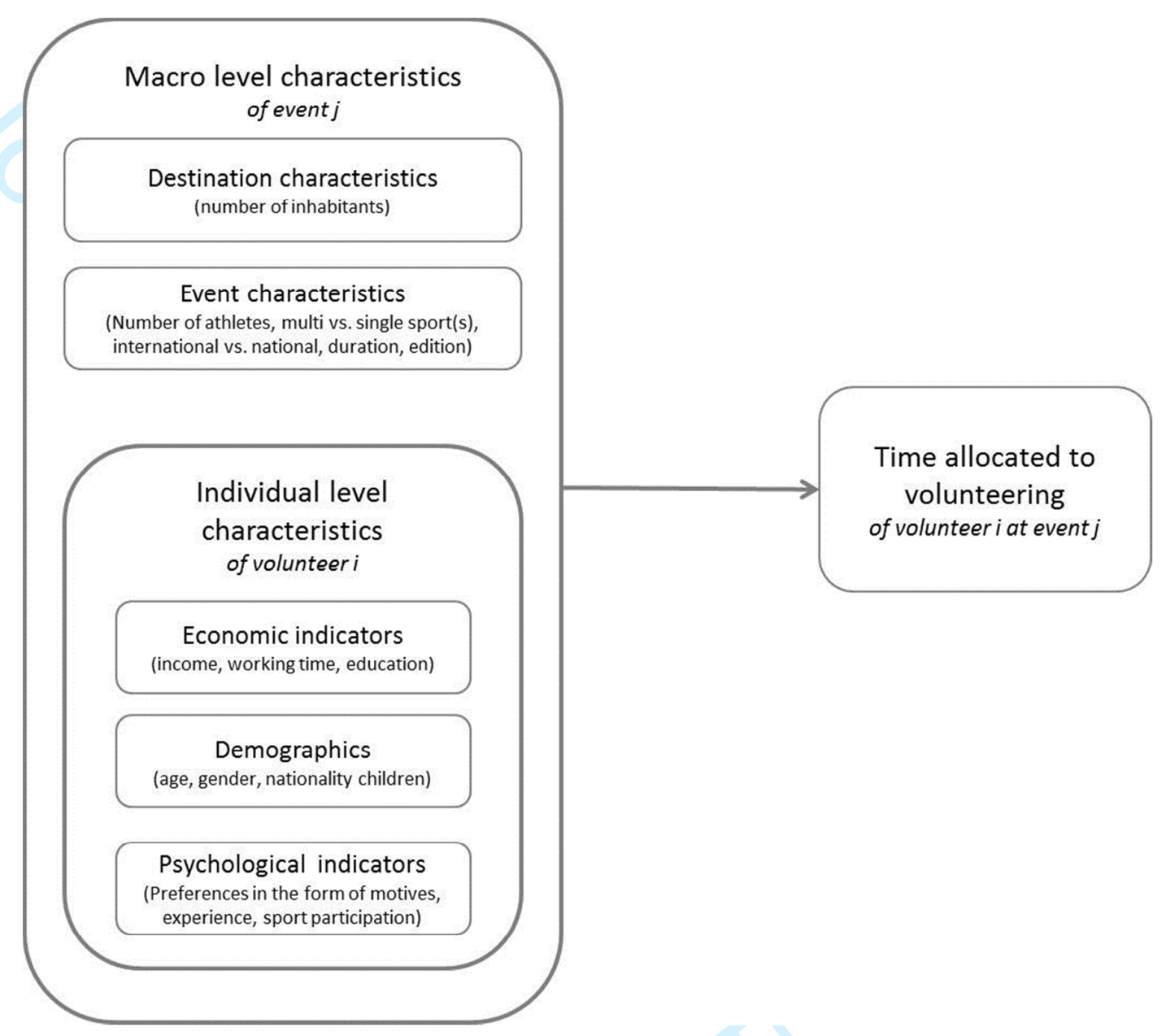

